\title{
New Data on some Coccinellidae (Coleoptera) from Iran
}

\author{
R. ABDOLAHI ${ }^{1}$, O. NEDVĚD ${ }^{2}$ and J. NOZARI ${ }^{1}$ \\ ${ }^{1}$ Department of Plant Protection, College of Agriculture and Natural Resources, \\ University of Tehran, Karaj, P.O.Box 31587-77871, Iran \\ ${ }^{2}$ Faculty of Science, Institute of Entomology, Biology Center, University of South Bohemia, Branišovská 31, \\ 37005 České Budějovice, Czechia
}

(Received: 4 October 2017; accepted: 3 November 2017)

\begin{abstract}
A species of ladybird beetles: Coccinella leonina transversalis Fabricius, is newly recorded from Iran. Identification keys to Iranian species of the genera Coccinella Linnaeus,, 1758, Pharoscymnus Bedel, 1906, subgenus Scymnus s.str. Kugelann, 1794 and redescription of Pharoscymnus horni (J. Weise, 1901) are given.
\end{abstract}

Keywords: Ladybird, ladybug, new record, key, redescription, Iran.

So far, 142 species of ladybird beetles (Coccinellidae) have been recorded from Iran (Abdolahi et al., 2016).

The only attempt with respect to identification key to Iranian lady beetles has been done by Abdolahi et al. (2017), which presents keys to Iranian genera of the former subfamilies Chilocorinae, Coccinellinae, Epilachinae and Microweiseinae. This paper provides an updated key to five Iranian species of the genus Coccinella Linnaeus, 1758, a key to eight Iranian species of the genus Pharoscymnus Bedel, 1906 and twelve species of the subgenus Scymnus s.str. Kugelann, 1794. Coccinella leonina transversalis Fabricius, 1781 (tribe Coccinellini) is recorded as new to Iran, and Pharoscymnus horni (J. Weise, 1901) is redescribed.

\section{Materials and Methods}

The samples were collected during April 2014 and 2015 by sweeping, in two provinces: Hormozgan and Kurdistan.

The beetles were killed by ethyl acetate. Larger beetles were mounted on pins (number 0-2) and small beetles were glued on card labels. All voucher specimens were deposited in the insect collection of Department of Plant Protection, University of Tehran, Karaj, Iran.

\footnotetext{
* Corresponding author; e-mail: Rahim.abdolahi@ut.ac.ir
} 
Taxonomy on the family and tribal level follows the phylogenetic reconstruction by Seago et al. (2011); the species level taxonomy and outlining of distribution follow the Catalogue of the Palaearctic Coccinellidae (Kovár̆, 2007).

\section{Results}

With a new record of lady beetles in this paper, the checklist of Iranian Coccinellidae is updated to 143 species. The number of species of the genus Coccinella recently known from Iran thus increased to five.

\section{Key to Iranian species of the genus Coccinella Linnaeus, 1758}

1 - Elytra with L-shaped spot Coccinella iranica Dobzhansky, 1926

- Elytra without L-shaped spot 2

2 - Elytra with transversal stripes (Fig. 1A) Coccinella leonina transversalis Fabricius, 1781 (Fig. 1)

- Elytra with separated spots, rarely with spots fused longitudinally 3

3 - Body length 5.3-7.6 mm, elytra with at most 7 separated spots, very rarely spots fused with each other Coccinella septempunctata Linnaeus, 1758

- Body length 4-6 mm, elytra with 11 spots

4 - Penis guide with warhead-shaped structure in distal part, elytral spots large Coccinella magnopunctata Rybakow, 1889

- Penis guide without warhead-shaped structure in distal part; elytral spots less than half of head width, sometimes emarginated by light ring

Coccinella undecimpunctata Linnaeus, 1758

\section{Key to Iranian subgenera of genus Scymnus Kugelann, 1794}

1 - Postcoxal line incomplete and not returning to anterior margin of abdominal ventrite 1 (Fig. 2C) Scymnus (Scymnus) Kugelann, 1794

- Postcoxal line complete and returning to anterior margin of abdominal

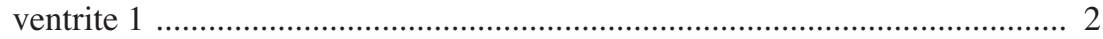

2 - Prosternal process with distinct carinae ...................................................... 3

- Prosternal process with carinae weak or missing

3 - Antenna with eleven antennomeres Scymnus (Mimopullus) Fürsch, 1987

- Antenna with ten antennomeres. Scymnus (Neopullus) Sasaji, 1971 


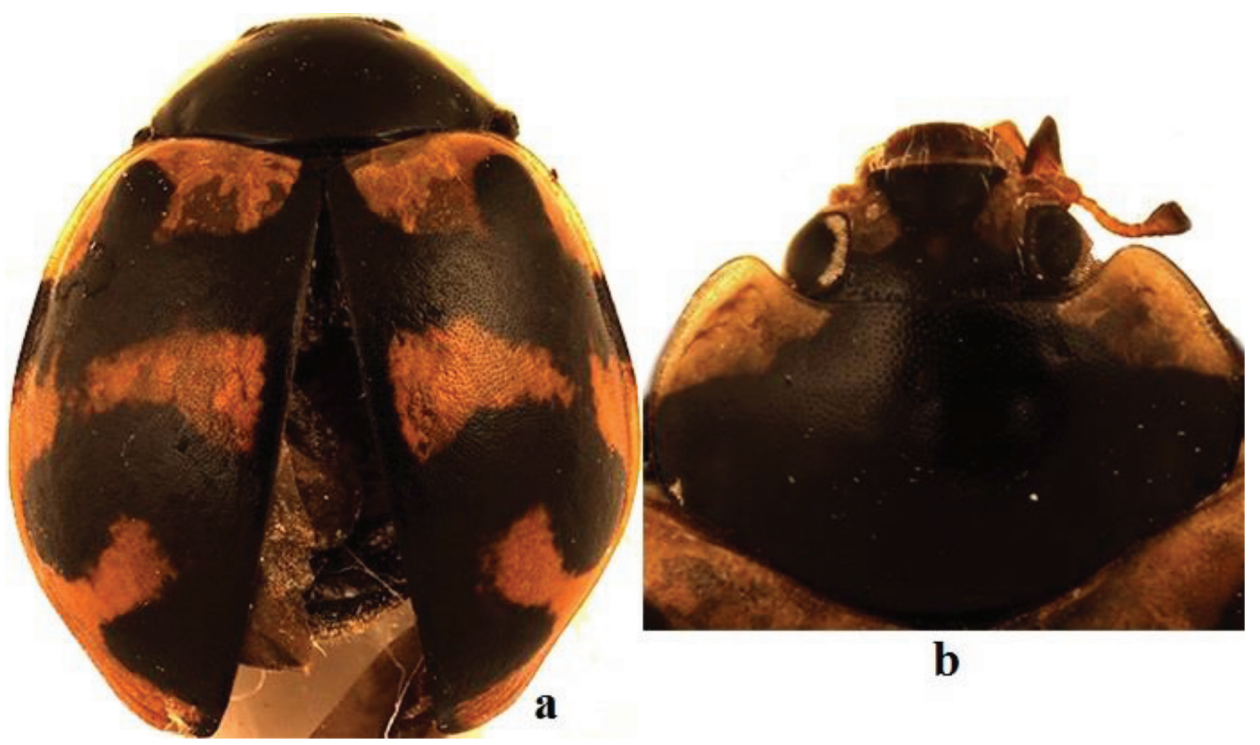

Fig. 1. Coccinella leonina transversalis. a) dorsal view of adult; b) dorsal view of pronotum and head

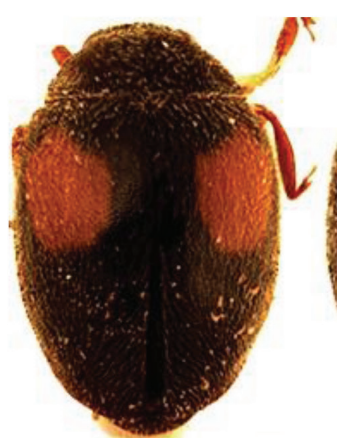

a

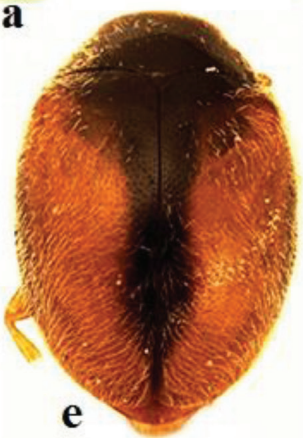

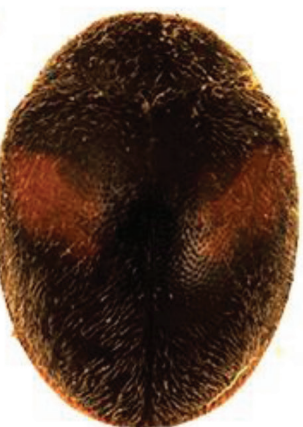

b

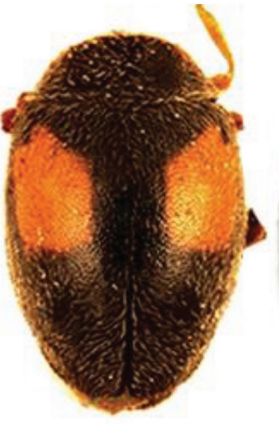

c

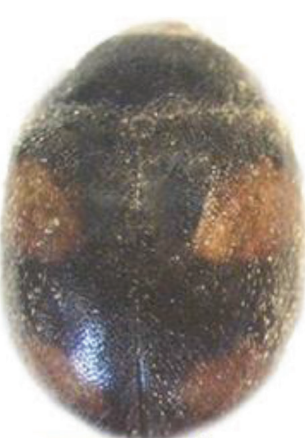

d

Fig. 2. Dorsal view of adults in species of subgenus Scymnus s.str.

a) Scymnus apetzi; b) Scymnus flavicollis; c) Scymnus frontalis; d) Scymnus magnomaculatus;

e) Scymnus nubilus; f) Scymnus rubromaculatus; g) Scymnus suffrianioides 
4 - Body and legs completely black

Scymnus (Scymnus) nigrinus Kugelann, 1794

- At least part of legs yellow or brown ............ Scymnus (Pullus) Mulsant, 1846

\section{Key to Iranian species of subgenus Scymnus s.str. Kugelann, 1794}

1 - Elytra black, without distinct spots or stripes …………………………….... 2

- Elytra with distinct spots or stripes ............................................................. 4

2 - All parts of legs black Scymnus nigrinus Kugellan, 1794

- At least part of legs light

3 - Basal half of femora black, parameres with dense hairs, penis guide as long as parameres or a bit longer .. Scymnus rubromaculatus (Goeze, 1777) (Fig. 2F)

- Femora entirely light, parameres with sparse hairs, penis guide distinctly longer than parameres Scymnus pallipes Mulsant, 1850

4 - Each elytron with two spots, anterior spot similar to an apple bitten from both sides Scymnus cedricolus Fursch, 1977

- Elytra with different pattern 5

5 - Anterior spots reaching anterior margin of elytra Scymnus manipulus Fürsch and Kreissl, 1967

- Spots not reaching anterior margin of elytra 6

6 - Each elytron with a large wide brownish patch covering most of elytron from almost anterior margin to posterior margin (Fig. 2E)

Scymnus nubilus Mulsant, 1850 (Fig. 2E)

- Each elytron with one or two orange spots 7

7 - Penis guide shorter than paramere (Fig. 3A)

Scymnus apetzi Mulsant, 1846 (Fig. 2A)

- Penis guide as long as paramere or longer 8

8 - Parameres without hairs, long and slender, penis guide even longer than parameres, each elytron with two spots

- Parameres short, stout, hairy

Scymnus suffrianioides Sahlberg, 1913 (Fig. 2G) sub-apical part (Fig. 3B), each elytron with one spot

Scymnus flavicollis J. R. Redtenbacher, 1843 (Fig. 2B)

- Parameres with hairs not grouped in two bunches (Fig. 3C,D), each elytron with one or two spots

10 - Penisguideinlateralviewwithadistinctangleventrally, widenearbaseandstrongly narrowed distally, parameres in lateral view with hairs covering penis guide but not crossing it (Fig. 3C), each elytron with one or two separated spots .... .Scymnus frontalis (Fabricius, 1787) (Fig. 2C) 

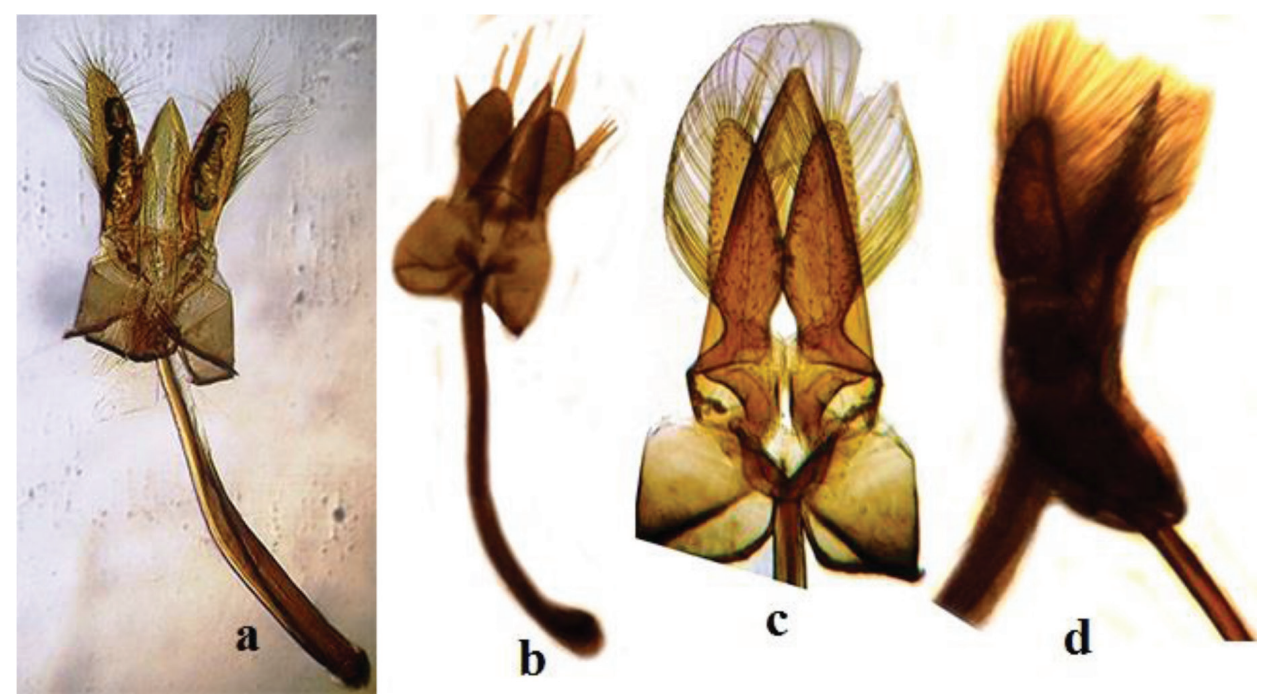

Fig. 3. Male genitalia-tegmen in subgenus Scymnus s.str. a) Scymnus apetzi; b) Scymnus flavicollis; c) Scymnus frontalis; d) Scymnus magnomaculatus

- Penis guide from lateral view entirely narrow or wide in more than half of its length, parameres from lateral view with long hairs covering penis guide and crossing it (Fig. 3D), each elytron with two large spots, rarely fused

Scymnus magnomaculatus Fursch, 1958 (Fig. 2D)

\section{Key to Iranian species of genus Pharoscymnus Bedel, 1906}

1 - Elytra with separated spots ...................................................................... 2

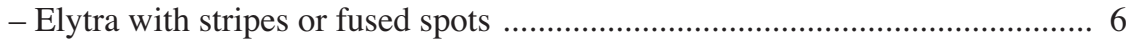

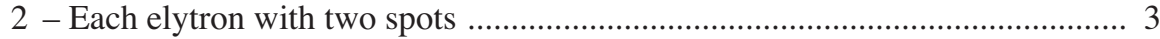

- Each elytron with three spots .................................................................. 4

3 - Postcoxal line distally joined with posterior margin of abdominal ventrite, anterior spots of elytra produced toward humerus

Pharoscymnus angohranensis Duverger, 1983

- Postcoxal line distally not joined with posterior margin of abdominal ventrite (Fig. 4E), anterior spots of elytra produced toward lateral side (Fig. 4A,B) ..... Pharoscymnus horni (J. Weise, 1901) (Fig. 4)

4 - Elytra brown-yellowish .................. Pharoscymnus flexibilis (Mulstant, 1853)

- Elytra black

5 - Pronotum with two yellowish spots in the corners, middle spots of elytra approximately circular-shaped Pharoscymnus fleischeri (J. Weise, 1883)

- Pronotum entirely black, middle spots of elytra oval 


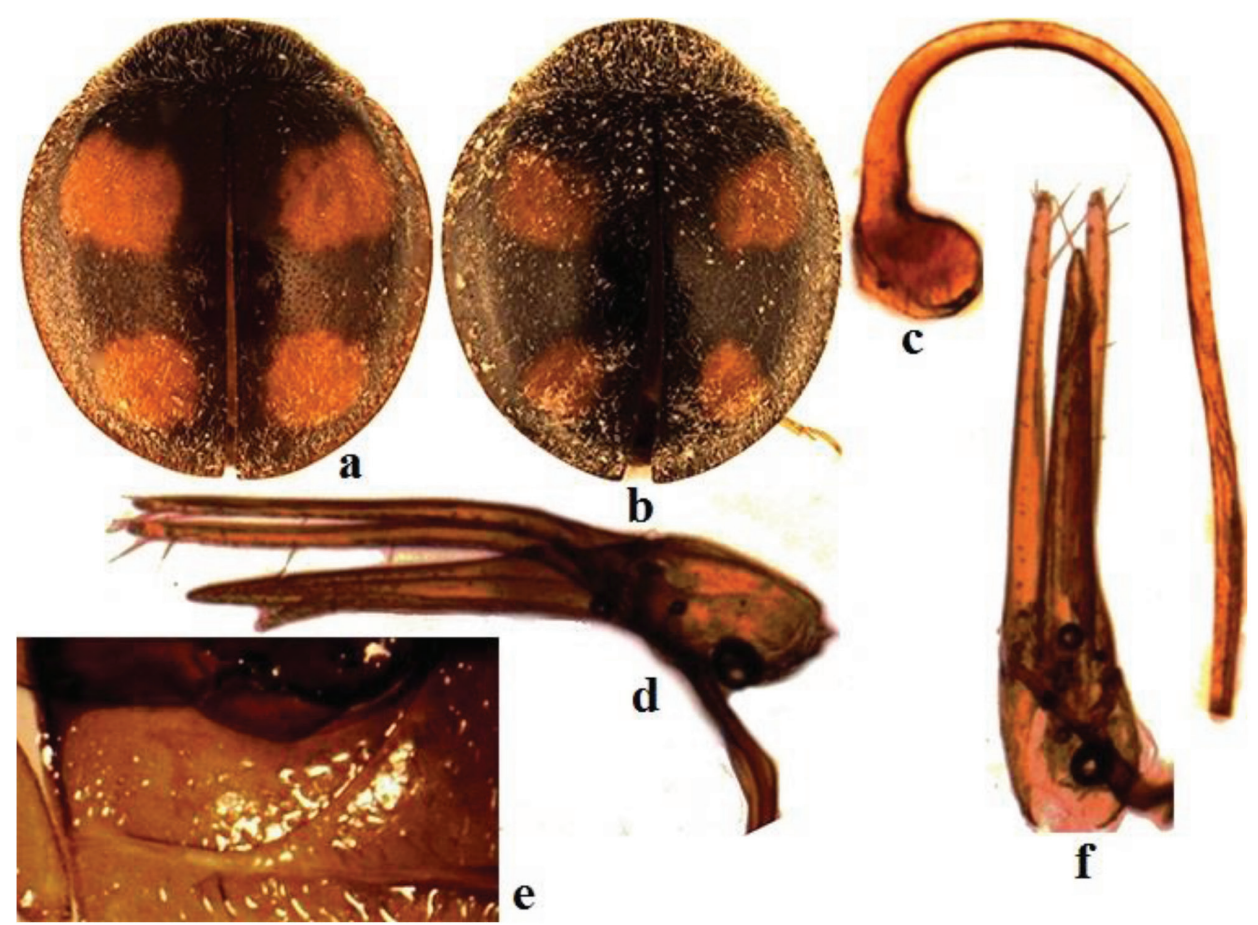

Fig. 4. Pharoscymnus horni. a-b) dorsal view of adult; a) younger individual; b) older individual;

c) male genitalia: penis; d) male genitalia: lateral view of tegmen; e) postcoxal line;

f) male genitalia: ventral view of tegmen

6 - Spots of elytra rounded (not angular), forming a yellow C, pronotum entirely black

- Spots of elytra angular, sometimes forming a flying bat, anterior margin of pronotum testaceous Pharoscymnus setulosus (Chevrolat, 1861)

7 - Body short oval. 8

- Body oblong oval................................ Pharoscymnus arabicus Fursch, 1979

8 - Spots reaching anterior and posterior margins of elytra

Pharoscymnus ovoideus Sicard, 1907

- Spots not reaching anterior and posterior margins of elytra....

..Pharoscymnus brunneosignatus Marder, 1949 


\section{Newly recorded species with diagnostic characters}

\section{Subfamily Coccinellinae}

Tribe Coccinellini

Genus Coccinella Linnaeus, 1758

Coccinella leonina transversalis Fabricius, 1781 (Fig. 1)

Diagnosis: body length 6.1-6.5, width 4.9-5.1 mm; smooth, convex, elongate oval, head black with two yellowish spots in inner margins of eyes (Fig. 1B), pronotum black with two yellowish spots in anterolateral corners (Fig. 1B), scutellum black, elytra background yellowish, elytra with black fused spots and stripes as in Fig. 1A, entire elytral suture black, postcoxal line incomplete.

Material examined: Kurdistan province: Sanandaj, alfalfa farm, $178 \mathrm{~m}$ a.s.l., $35^{\circ} 19^{\prime} 32^{\prime \prime N} 47^{\circ} 2^{\prime} 44^{\prime \prime E}, 3$ adults, 12 Apr 2014, sampled by Hamed Ghobari.

Distribution in Iran: Kurdistan.

General distribution: Bhutan, China (Fujian, Guandong, Hainan), India, Nepal, Taiwan, Australia, Oriental region.

\section{Redescribed species}

\section{Tribe Sticholotidini}

Genus Pharoscymnus Bedel, 1906

Pharoscymnus horni (J. Weise, 1901) (Fig. 4)

Diagnosis: body length $1.98-2.21 \mathrm{~mm}$, width $1.70-1.88$, quite convex and rounded, younger (teneral) individuals brownish (Fig. 4A), older individuals blackish (Fig. 4B), ventral side uniformly dark brown, antenna short and ten-segmented, last maxillary palpomere elongate, pronotum black and covered with dense hairs, elytral margins flattened, elytra covered with hairs, each elytron with two brownish spots, anterior spots approximately oblique and rectangular, posterior spots approximately circular (Fig. 4A,B), postcoxal line incomplete, approaching and running parallel with posterior margin of abdominal ventrite (Fig. 4E), penis guide shorter and wider than parameres, parameres with sparse bristles (Fig. 4D,F), basal part of penis clubbed, distal part simple (Fig. 4C).

Material examined: Hormozgan province: Rodan Bika, mango garden, $178 \mathrm{~m}$ a.s.1., $27^{\circ} 21^{\prime} 48^{\prime \prime N} 57^{\circ} 10^{\prime} 27^{\prime \prime} \mathrm{E}, 9$ adults, 21 Apr 2015, sampled by Rahim Abdolahi.

Distribution in Iran: Sistan and Baluchistan (Latibari, 2017), Hormozgan (present paper).

General distribution: India, Sri Lanka, Pakistan.

\section{Discussion}

Coccinella leonina transversalis has a wide range of distribution including southeastern parts of the Palearctic region, but the country nearest to Iran with published record is India. Since we recorded this species in northwest of Iran, this might be either a result of introduction or we may expect its occurrence also in other provinces of Iran and in Pakistan. 
Pharoscymnus horni is distributed in the Oriental region and Palaearctic countries and provinces adjacent to the Oriental region. Hormozgan in south of Iran has such climatic and biogeographic conditions that natural occurrence of this species can be expected. It is very similar to other species of the genus Pharoscymnus. So the best way to identify species of the genus is extracting male genitalia.

The Iranian species of the subgenus Scymnus s. str. are very similar to each other. No identification key for them was available so far. The key and photos in this paper could result in easy identification of the Iranian species of the subgenus.

\section{Acknowledgements}

We are grateful to Dr. Hamed Ghobari (Department of Plant Protection, University of Kurdistan, Iran) for sending samples of species Coccinella leonina transversalis to us. Also we appreciate Dr. Janakiraman Poorani (Project Directorate of Biological Control, H.A. Farm Post, Bangalore, India) for guiding us in identifying of species Pharoscymnus horni.

\section{Literature}

Abdolahi, R., Nozari, J., Allahyari, H. and Khormizi, M. (2016): Checklist and distribution of lady beetles (Coleoptera: Coccinellidae) in Iran. International J. Animal Biosystematics. 12, 1-35.

Abdolahi, R., Nedvěd, O. and Nozari, J. (2017): A Key to genera of Iranian lady beetles (Coleoptera: Coccinellidae) of subfamilies Chilocorinae, Coccinellinae, Epilachinae and Microweiseinae. Acta Phytopathol. et Entomol. Hung. (accepted).

Kovář, I. (2007): Coccinellidae. In: I. Löbl and A. Smetana (eds): Catalogue of Palaearctic Coleoptera. Vol. 4. Apollo Books, Stenstrup, pp. 568-631.

Latibari, M. H., Zare Khormizi, M. and Moravvej, G. (2017): First record of an important agent in scales biocontrol, Pharoscymnus horni (Weise, 1900) (Coleoptera: Coccinellidae) from Iran. J. Entomology and Zoology Studies. 5, 310-311.

Seago, A. E., Giorgi, J. A., Li, J. and Ślipiński, A. (2011): Phylogeny, classification and evolution of ladybird beetles (Coleoptera: Coccinellidae) based on simultaneous analysis of molecular and morphological data. Molecular Phylogenetics and Evolution, 60, 137-151. 